\title{
Effect of Austempering and Martempering on the Properties of AISI 52100 Steel
}

\author{
P. Vamsi Krishna, ${ }^{1}$ R. R. Srikant, ${ }^{2}$ Mustafa Iqbal, $^{3}$ and N. Sriram ${ }^{3}$ \\ ${ }^{1}$ Department of IPE, GITAM University, Visakhapatnam 530045, India \\ ${ }^{2}$ Department of Mechanical Engineering, GITAM University, Visakhapatnam 530045, India \\ ${ }^{3}$ Department of IPE, GITAM University, Visakhapatnam 530045, India \\ Correspondence should be addressed to P. Vamsi Krishna; vamsikrishna16@gitam.edu
}

Received 1 June 2012; Accepted 4 July 2012

Academic Editors: L. Bourithis and J. Mao

Copyright (C) 2013 P. Vamsi Krishna et al. This is an open access article distributed under the Creative Commons Attribution License, which permits unrestricted use, distribution, and reproduction in any medium, provided the original work is properly cited.

\begin{abstract}
The mechanical properties of steel decide its applicability for a particular condition. Heat treatment processes are commonly used to enhance the required properties of steel. The present work aims at experimentally investigating the effect of austempering and martempering on AISI 52100 steel. Different tests like microstructure analysis, hardness test, impact test, and wear test are carried out after heat treatment process. It was found that annealed steel was least hard and more wear prone, while martempered steel was hardest and least vulnerable to wear. Austempered steel had the highest impact strength and it is increased with soaking time up to certain level. Least wear rate is observed in martempered sample both in abrasion and dry sliding. However, least friction coefficient is shown by annealed samples.
\end{abstract}

\section{Introduction}

The knowledge of materials and their properties is of great significance for a production engineer. The machine elements should be made of a material that has properties suitable to the operating conditions. For instance, AISI 52100 is a high carbon alloy steel which achieves a high degree of hardness with compressive strength and abrasion resistance used in ball and roller bearings, spinning tools, punches, and dies. In such cases, to achieve the required properties heat treatment methods are commonly used.

Martempering is a common heat treatment process that quenches the material to an intermediate temperature just above the martensite start temperature $\left(M_{s}\right)$ and then cools air through the martensitic transformation range to room temperature [1-4]. It is important to air-cool throughout the transformation range since rapid cooling through this range is required to produce residual stress patterns similar to those produced by a direct quench and negate any advantages of the process [5]. Modified martempering (MM) is a similar technique wherein the intermediate quench temperature is below $M_{s}$ but above the martensite finish temperature $\left(M_{f}\right)$
$[3,4]$. Tempering of martempered or modified martempered steels to the desired hardness and tensile strength is performed identically to that in quench and temper operations with better impact resistance. Commonly martempered steels include AISI 1090, 4140, 4340, 6050, and SAE 52100 [3].

Austempering is a method of hardening steel by quenching from the austenitizing temperature into a heat extracting medium (usually molten salt) which is maintained at specified temperature level between $200^{\circ} \mathrm{C}$ and $400^{\circ} \mathrm{C}$ and holding the steel in this medium until austenite is transformed to bainite. This method is used to increase strength, toughness, and to reduce distortion. The two processes are heating a medium-to-high carbon ferrous metal to an austenitic condition then cooling the object rapidly enough to avoid the formation of pearlite to a temperature above $M_{s}$ temperature and isothermally holding the part for a time sufficient to produce the desired microstructure. But these two processes are generally limited to small components.

Due to their high applicability, these processes are explored by many researchers. The amount of retained austenite in Cr-Mo steels used in mill liner was studied by Shaeri et al. [6]. The effects of heat treatments including direct 
quenching, martempering, and austempering on the retained austenite existing in the microstructure of these steels were investigated. Specimens were austenitized at $950^{\circ} \mathrm{C}$ followed by direct quenching using compressed and still air. The specimens were also isothermally quenched in salt bath at $200^{\circ} \mathrm{C}$ and $300^{\circ} \mathrm{C}$ for $2,8,30$, and $120 \mathrm{~min}$. The existence of the retained austenite in the microstructure of this steel led to some drawbacks. Wear resistance of the material was reduced as a result of the presence of phase with low hardness and strength. Unfavorable dimensional variations appear in the specimens resulting from the transformation of austenite to martensite during tempering or upon severe impacts applied to the liners during milling process. Transformation of austenite to martensite during tempering gives rise to a volume change in austenite resulting in the formation of a severe compressive stress at the austenite-martensite boundary. Such a defect forms a suitable place for crack nucleation and therefore reduces durability of the specimen. The results showed that the lowest amount of retained austenite in the microstructure was obtained in the specimens quenched isothermally at $300^{\circ} \mathrm{C}$ for $120 \mathrm{~min}$.

The effect of austempering treatment on microstructure and mechanical properties of high-Si steel was studied by Mandal et al. [7]. In this investigation, the influence of austempering treatment on the microstructure and mechanical properties of silicon alloyed cast steel has been evaluated. The experimental results showed that an ausferrite structure consisting of bainitic ferrite and retained austenite can be obtained by austempering the silicon alloyed cast steel at different austempering temperature. TEM (Transmission Electron Microscope) observation and X-ray analysis confirmed the presence of retained austenite in the microstructure after austempering at $400^{\circ} \mathrm{C}$. The austempered steel has higher strength and ductility compared to as-cast steel. With increasing austempering temperature, the hardness and strength decreased but the percentage of elongation increased. A good combination of strength and ductility was obtained at an austempering temperature of $400^{\circ} \mathrm{C}$.

Maclejewski and Regulski [8] studied the fracture assessment of martempered and quenched and tempered AISI 4140 low alloy steel. The reported advantages of martempering include less distortion, elimination of quench cracking, improved fatigue resistance, and improved absorbed impact energy. Data regarding improved impact energy are sparse and appear to be most widely reported for the high-carbon steels. The results of impact energy and tensile strength that are compared between quenched and tempered to that of modified martempered had no much difference, and the analyst must check for the martempering process.

Wear resistance properties of Austempered Ductile Iron (ADI) were studied by Lerner and Kingsbury [9]. A detailed review of wear resistance properties of ADI was undertaken to examine the potential applications of this material for wear parts, as an alternative to steels, alloyed and white irons, bronzes, and other competitive materials. Two modes of wear were studied: adhesive (frictional) dry sliding and abrasive wear. In the rotating dry sliding tests, wear behavior of the base material (a stationary block) was considered in relationship to counter surface (steel shaft) wear. In this
TABLE 1: Composition of AISI 52100 Steel.

\begin{tabular}{lccccccc}
\hline $\mathrm{C}$ & $\mathrm{Mn}$ & $\mathrm{Si}$ & $\mathrm{P}$ & $\mathrm{S}$ & $\mathrm{Ni}$ & $\mathrm{Cr}$ & $\mathrm{Mo}$ \\
\hline 0.92 & 0.62 & 0.25 & 0.035 & 0.03 & 0.04 & 1.25 & 0.02 \\
\hline
\end{tabular}

wear mode, the wear rate of ADI was only one-fourth that of pearlitic ductile iron (DI). Only quenched DI with a fully martensitic matrix slightly out performed ADI. No significant difference was observed in the wear of steel shafts running against ADI and quenched DI. The excellent wear performance of ADI and its counter surface, combined with their relatively low-friction coefficient, indicate potential for dry sliding wear applications. In the abrasive wear mode, the wear rate of ADI was comparable to that of alloyed hardened AISI 4340 steel, and approximately one-half that of hardened medium carbon AISI 1050 steel and of white and alloyed cast irons. The wear resistance of ADI may be attributed to the strain-affected transformation of high-carbon austenite to martensite that takes place in the surface layer during the wear tests.

Jetley [10] reported improvement in wear properties of aircraft brake steel rotors by martempering. Martempering process using oil- and water-based quenchants at lower temperature is adopted in this work. The test samples were evaluated for hardness, distortion, and wear under accelerated simulated tests. The results show that although both hardness and wear resistances were lower compared to the austempering, they met the design intent. Also the wear rate of martempered samples was more consistent which may provide advantages for maintenance purposes.

Wear of hard-turned AISI 52100 steel was studied by Bartha et al. [11]. High precision machining such as hard turning changes the surface and the material properties of steel alloys. A sliding block-on-cylinder wear tester was used for the purpose of testing the wear performance of AISI 52100-bearing steel. The effect of microstructure on the wear performance of hard-turned steel showed that the white layer and overtempered martensite (OTM) had a higher wear resistance than martensite. The wear mechanism dependence on the surface hardness was attributed to this increase in wear performance. The near-surface residual stress of the material was shown to become more compressive as the material wore down. The applied normal loads affected the surface roughness, residual stresses, and, in turn, the wear performance of the material.

\section{Experimentation}

The chemical composition of the investigated steel is determined by optical emission spectrometer and shown in Table 1. The dimensions of the as-cast specimens were $75 \mathrm{~mm} \times$ $25 \mathrm{~mm} \times 12 \mathrm{~mm}$ for abrasive wear test, $75 \mathrm{~mm} \times 10 \mathrm{~mm} \times$ $8 \mathrm{~mm}$ for impact test, and $6 \mathrm{~mm}$ diameter pins of $30 \mathrm{~mm}$ length for pin on disc test, respectively. All specimens were annealed at $950^{\circ} \mathrm{C}$ for $1 \mathrm{hr}$ to homogenize the as-cast microstructure of the specimens. Same set of specimens was, initially, austenitized at $950^{\circ} \mathrm{C}$ for $1 \mathrm{hr}$ and then, held in salt bath (mixture of sodium nitrate-30\%, potassium 


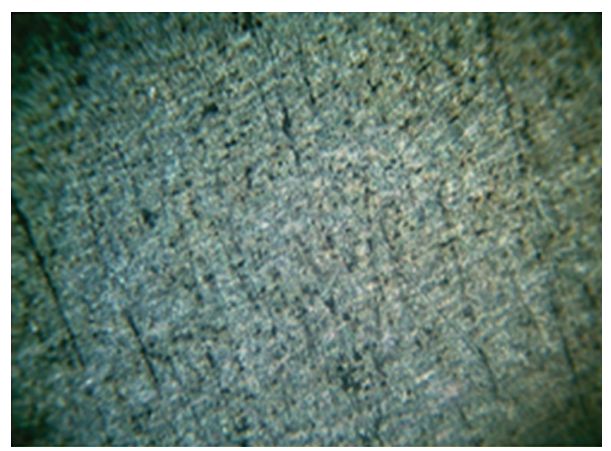

(a) Annealed specimen

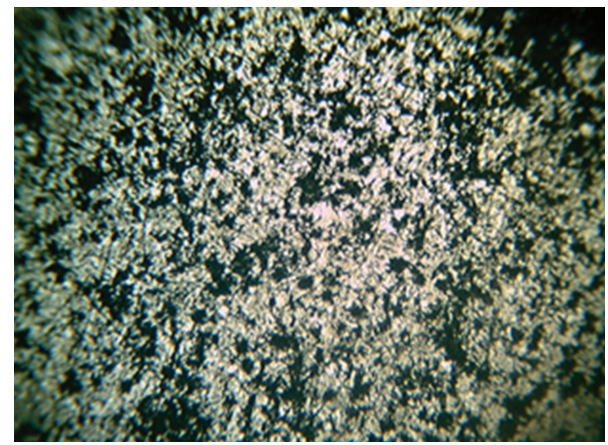

(c) Austempered specimen with 10 minutes soaking time

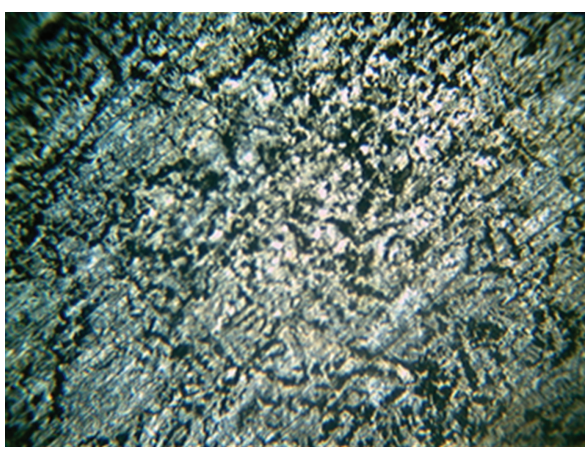

(b) Martempered specimen

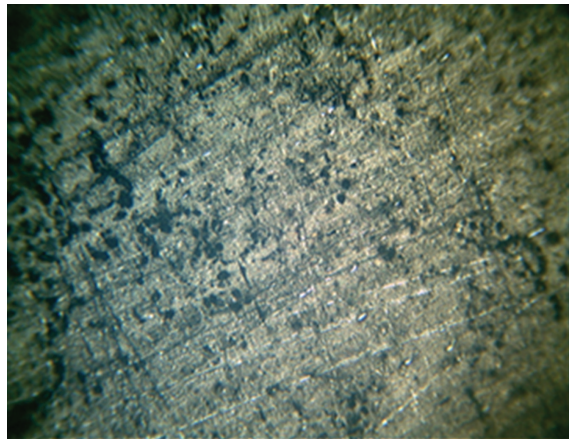

(d) Austempered specimen with 20 minutes soaking time

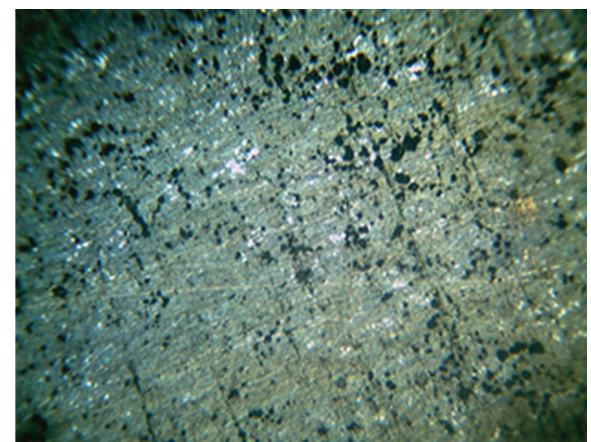

(e) Austempered specimen with 30 minutes soaking time

Figure 1: Microstructure of different heat-treated samples $(\times 100 \mu \mathrm{m})$.

nitrate- $40 \%$ and calcium nitrate- $30 \%$ ) at $160^{\circ} \mathrm{C}$ for $15 \mathrm{~min}$, after that quenched in water in martempering process. In austempering, specimens are austenitized at $950^{\circ} \mathrm{C}$ for $1 \mathrm{hr}$ and held in salt bath (mixture of sodium nitrate-50\% and potassium nitrate-50\%) at $350^{\circ} \mathrm{C}$ for $10 \mathrm{~min}, 20 \mathrm{~min}$, and $30 \mathrm{~min}$ and then cooled to room temperature in still air.

For microstructural analysis, specimens have been prepared based on the standard ASTM E3. To etch the specimens, the sodium metabisulfite solution (15\%) has been used in accordance with the ASTM E407. The optical micrographs were taken according to the standard ASTM E883 using radical microscope $(\mathrm{RMM}-77)$ with $\times 100$ magnification. All the specimens are tested for impact strength in Izod impact test of standard ASTM D256. Hardness tests were performed and $\mathrm{BHN}$ is calculated as per ASTM E10. Abrasive wear of the specimens is measured using DUCOM abrasion tribometer according to ASTM G65 with application of $5 \mathrm{~kg}$ load at $200 \mathrm{rev} / \mathrm{min}$. Dry sliding test is conducted on pin disc apparatus against EN32 steel disc having hardness of $470 \mathrm{Hv}$ to measure coefficient of friction based on standard ASTM G99.

\section{Results and Discussions}

3.1. Microstructure. The images were captured in a metallurgical microscope from prepared samples to study the microstructure changes. Figure 1(a) shows the microstructure of annealed specimen, which consists of small black dots with good distribution. These black dots are interpreted as carbide present in the structure. The structure of the 


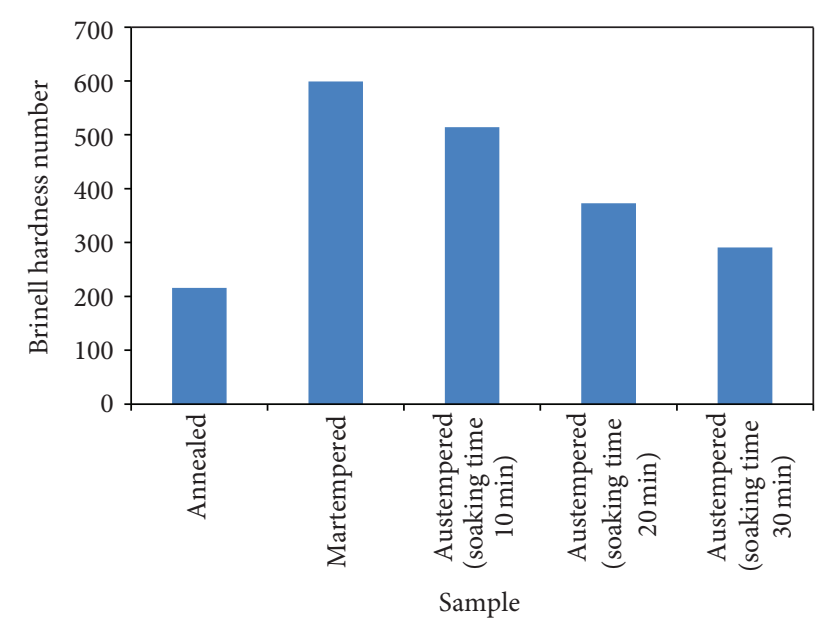

FIGURE 2: Brinell hardness number of heat treated samples.

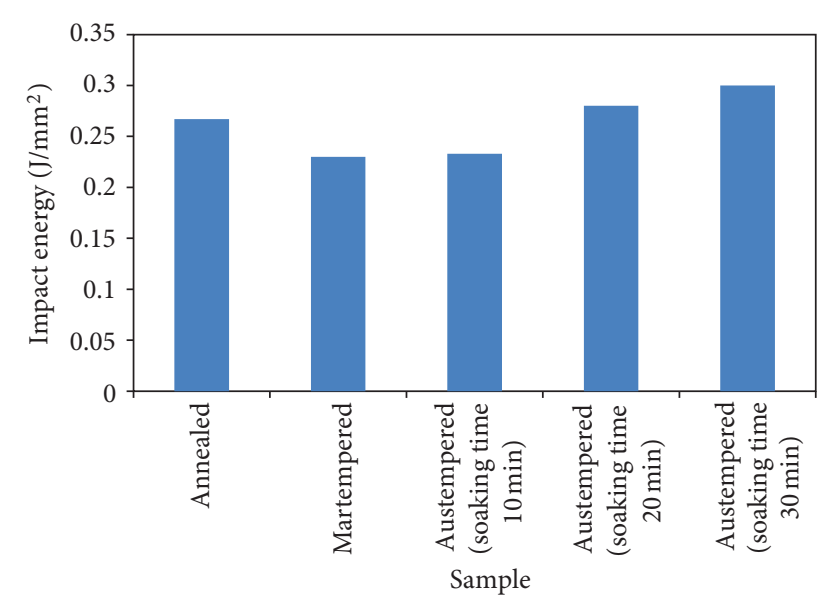

FIGURE 3: Impact strength of heat treated samples.

martempered sample (Figure 1(b)) is completely covered with carbides and has a very rich density of these all over the surface. Austempered specimen with 10 min soaking time shows good density of carbides (Figure 1(c)) but is lesser than the martempered sample. Compared to 10 min soaking time, specimen with 20 min soaking time has less carbide (Figure 1(d)). Figure 1(e) shows the microstructure of austempered specimen with $30 \mathrm{~min}$ soaking time. The sample has good number of carbides but occurs only in some areas. The above samples have different microstructures and their hardness varies with amount of carbides.

The samples which were annealed have fewer carbides with massive pearlite compared to remaining samples and as such it is least hard as the carbides are retained in solution. Martempered sample has a microstructure rich with carbide or martensite which is the hardest steel structure. In austempered sample, the structure is filled with the carbide but lesser than martempered sample, the reason being that it is soaked in salt bath maintained at $340^{\circ} \mathrm{C}$ for $10 \mathrm{~min}$ and then quenched it in water. This allows conversion of austenite into bainite only for $10 \mathrm{~min}$ with the remaining

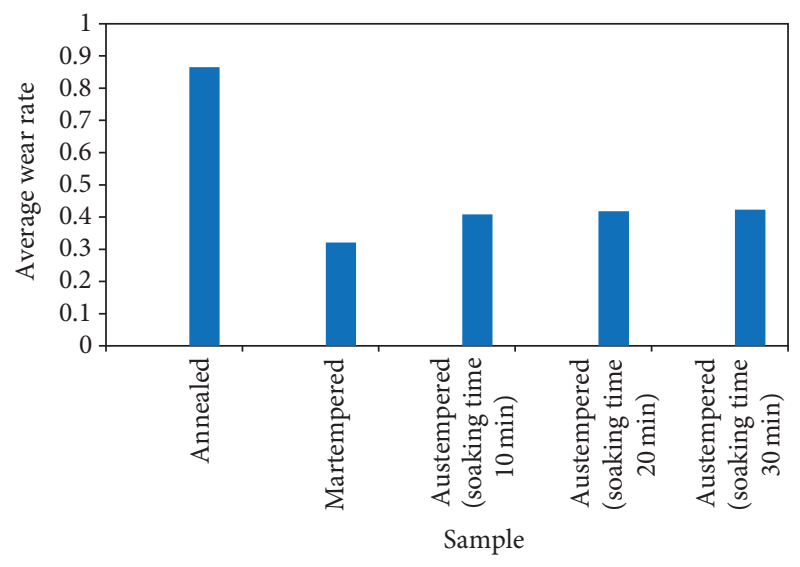

FIGURE 4: Average wear rate $(\mathrm{g} / \mathrm{min})$ of heat treated samples in abrasion wear test.

converting into martensite. Similarly, the sample which was soaked for $20 \mathrm{~min}$ has had bainite conversion for only $20 \mathrm{~min}$, after quenching the remaining converts in to martensite. Also as the austempered sample with soaking time $30 \mathrm{~min}$ gets converted to bainite structure from austenite till $30 \mathrm{~min}$ and after quenching the remaining converts in to martensite. This is evident from the structures observed which shows the density of carbide.

3.2. Hardness. The Brinell's hardness number of different heat treated samples showed (Figure 2) that the martempered sample was the hardest among the samples followed by the austempered samples with soaking time 10,20, and $30 \mathrm{~min}$, respectively, and annealed, which was least hard of all. As expected with reference from the microstructure test, the martempered sample is the hardest because of conversion of austenite into martensite structure. Austempered sample, which has been soaked in salt bath maintained at $340^{\circ} \mathrm{C}$ for $10 \mathrm{~min}$, has conversion of austenite into bainite only for $10 \mathrm{~min}$, with the remaining converting into martensite after quenching in water. As the soaking time increases the conversion time and conversion of austenite into bainite increase and the conversion of martensite decreases as such the hardness decreases. The annealed sample exhibits the least hardness among the tested samples for the hardness.

3.3. Impact Strength. Impact strength of all the specimens obtained from Izod impact test is shown in Figure 3. The moderate impact strength was observed for annealed sample. Martempered sample shows least impact strength due to formation of martensite. Austempered samples impact strength was improved because of the presence of bainite and it is observed that impact strength was improved with soaking time in austempering.

3.4. Abrasion Wear. After the experiments were conducted in the prescribed procedure, the weight loss for every reading was noted till a steady or nearer to steady state arrived. The wear rate is given by weight loss for one min. Variation of 


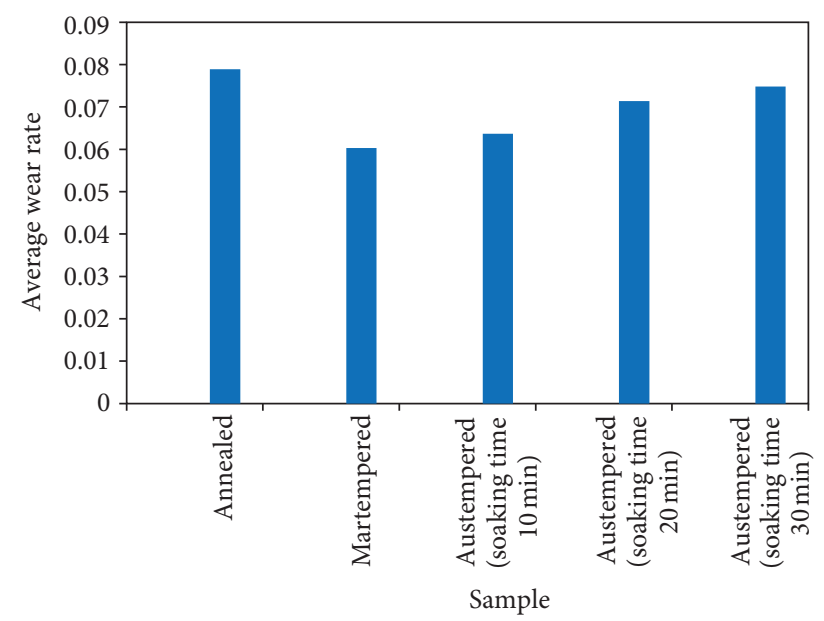

Figure 5: Average wear rate $(\mathrm{g} / \mathrm{min})$ of heat treated samples in dry sliding test.

weight loss for each minute with constant speed of rotation is measured and average weight loss is calculated. From weight loss, wear rate for each minute and average wear rate are calculated and presented in Figure 4. The result clearly indicates that the martempered sample has the least wear rate. The austempered sample with soaking time of $10 \mathrm{~min}$ has the next least wear rate followed by $20 \mathrm{~min}$ soaked and $30 \mathrm{~min}$ soaked. Annealed sample has the more wear rate compared to other samples. This shows that the martempered sample is having good wear resistance followed by the austempered samples. This also indirectly indicates the hardness acquired by the sample in the heat treatment process.

3.5. Dry Sliding Wear. The weight loss of heat treated samples with respect to time in dry sliding test is measured. The average wear rate of heat treated samples with respect to time in dry sliding test is presented in Figure 5. The bar graph clearly indicates that the most effected pin is annealed when compared to all the pins and the least effected is martempered. The annealed pin had a burr formation at the end which was kept on the tungsten disc. This indicates that a lot of heat was formed at the end which deformed the portion of that end plastically. Also this suggests that the material was more ductile than that of the remaining samples.

The pin on disc experiment was done till steady friction value was obtained. After every reading, the friction value for each sample was measured and also the average friction coefficient value (Figure 6) was calculated. It is observed that average friction value is less for annealed one and increased in martempered and austempered samples.

\section{Conclusion}

AISI 52100 steel was subjected to various heat treatments for enhancing the material properties. From the present study the following conclusions are drawn.

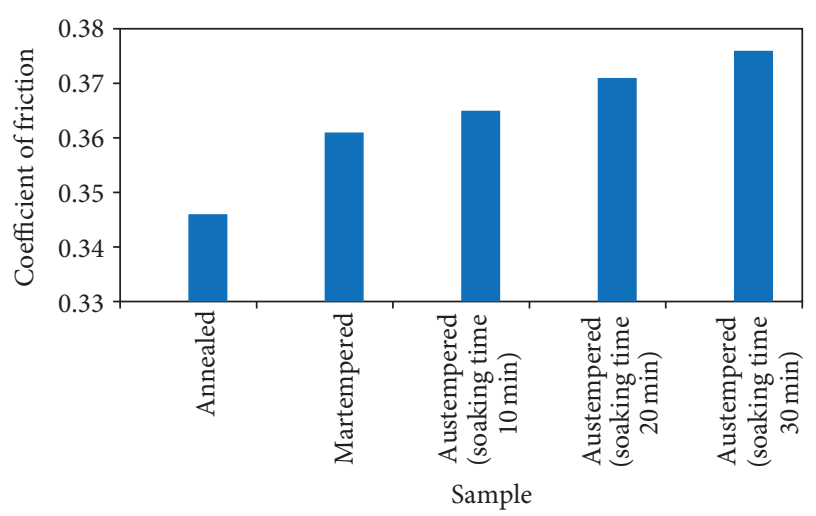

FIGURE 6: Average friction coefficient of different heat treated samples.

(i) Annealed samples have less carbide in micro structure and are least hard, whereas martempered samples have dense carbide indicating highest hardness. Hardness increased three times with martempering process.

(ii) Austempered samples have highest impact strength, the least being martempered samples. The impact strength increased with soaking time in austempered samples up to certain level. $20 \%$ improvement is observed with austempering process.

(iii) Annealed samples have the highest wear, while martempered samples have the least wear. Approximately $50-60 \%$ wear resistance is increased with martempering process.

(iv) Friction coefficient is increased with both the heat treatment processes.

Based on the functional requirement, the choice can be made among the heat-treated AISI 52100 steels.

\section{References}

[1] G. Krauss, Steels: Heat Treatment and Processing Principles, ASM International, Materials Park, Ohio, USA, 1990.

[2] W. F. Smith, Structure and Properties of Engineering Alloys, McGraw-Hill, New York, NY, USA, 2nd edition, 1993.

[3] H. Chandler, Heat Treater's Guide: Practices and Procedures for Irons and Steels, ASM International, Materials Park, Ohio, USA, 1995.

[4] H. Weber and W. J. Laird, "Martempering of steel," in ASM Metals Handbook, pp. 137-138, ASM International, Materials Park, Ohio, USA, 1991.

[5] F. Abbasi, A. J. Fletcher, and A. B. Soomro, "A critical assessment of the hardening of steel by martempering," International Journal of Production Research, vol. 25, no. 7, pp. 1069-1080, 1987.

[6] M. H. Shaeri, H. Saghafian, and S. G. Shabestari, "Effects of austempering and martempering processes on amount of retained austenite in Cr-Mo steels (FMU-226) used in mill liner," Journal of Iron and Steel Research International, vol. 17, no. 2, pp. 53-58, 2010. 
[7] D. Mandal, M. Ghosh, J. Pal et al., "Effect of austempering treatment on microstructure and mechanical properties of high-Si steel," Journal of Materials Science, vol. 44, no. 4, pp. 1069-1075, 2009.

[8] J. Maclejewski and C. Regulski, "Fracture assessment of martempered and quenched and tempered alloy steel," Journal of Failure Analysis and Prevention, vol. 9, no. 5, pp. 397-408, 2009.

[9] Y. S. Lerner and G. R. Kingsbury, "Wear resistance properties of austempered ductile iron," Journal of Materials Engineering and Performance, vol. 7, no. 1, pp. 48-53, 1997.

[10] S. Jetley, "Martempering to improve wear properties of aircraft brake steel rotors," Journal of Industrial Technology, vol. 23, no. 2, pp. 1-10, 2007.

[11] B. B. Bartha, J. Zawadzki, S. Chandrasekar, and T. N. Farris, "Wear of hard-turned AISI 52100 steel," Metallurgical and Materials Transactions A, vol. 36, no. 6, pp. 1417-1425, 2005. 

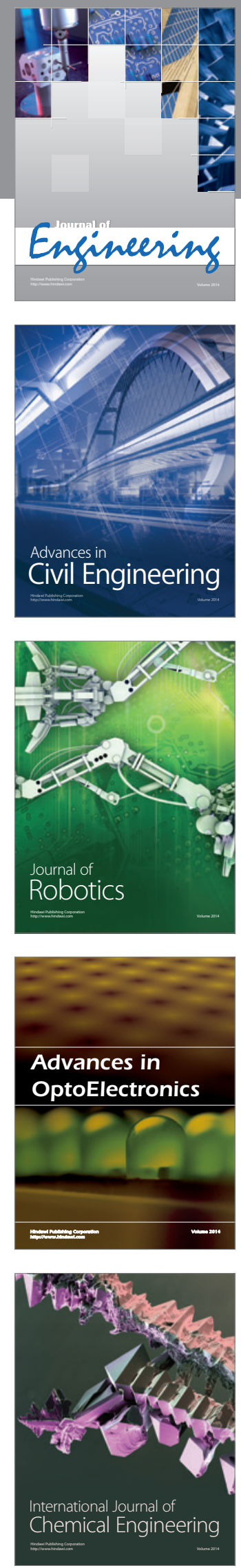

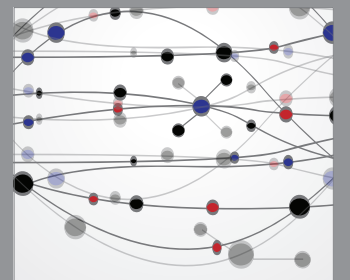

The Scientific World Journal
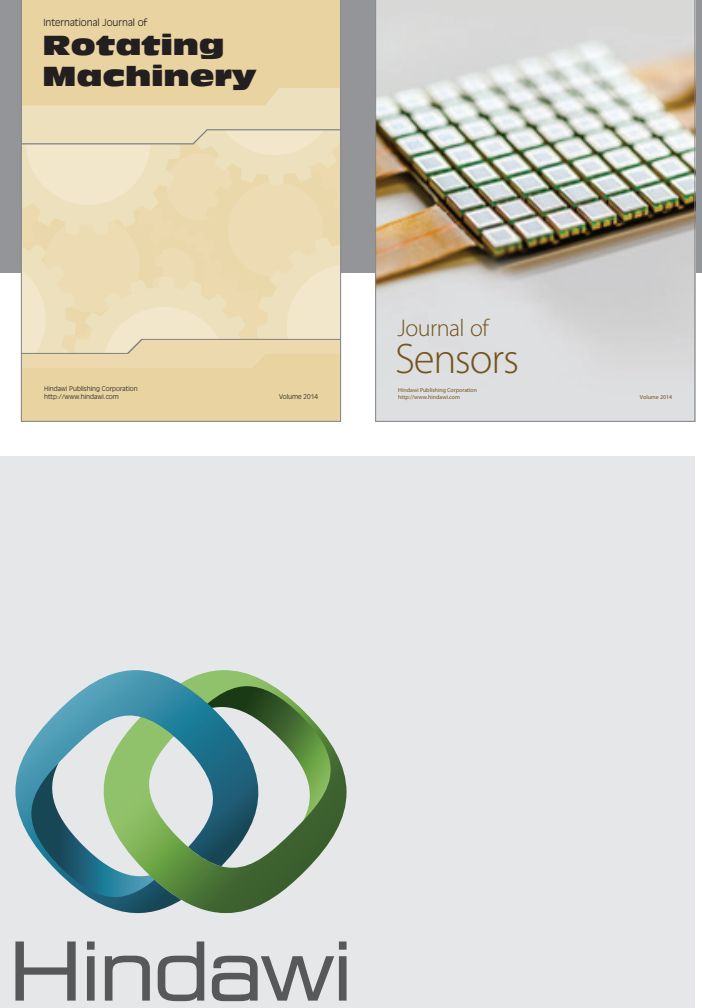

Submit your manuscripts at http://www.hindawi.com
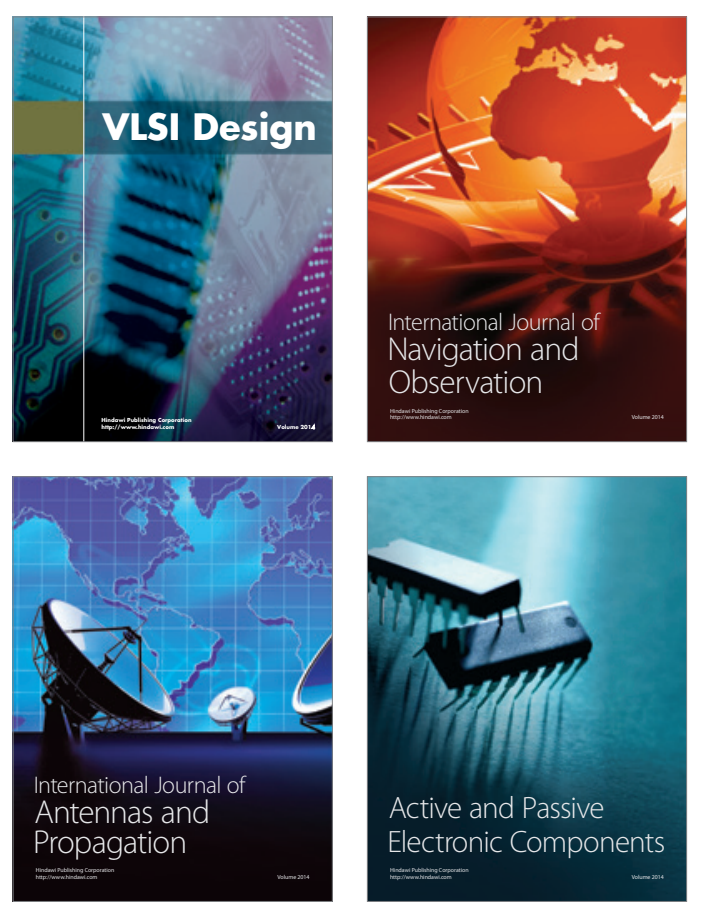
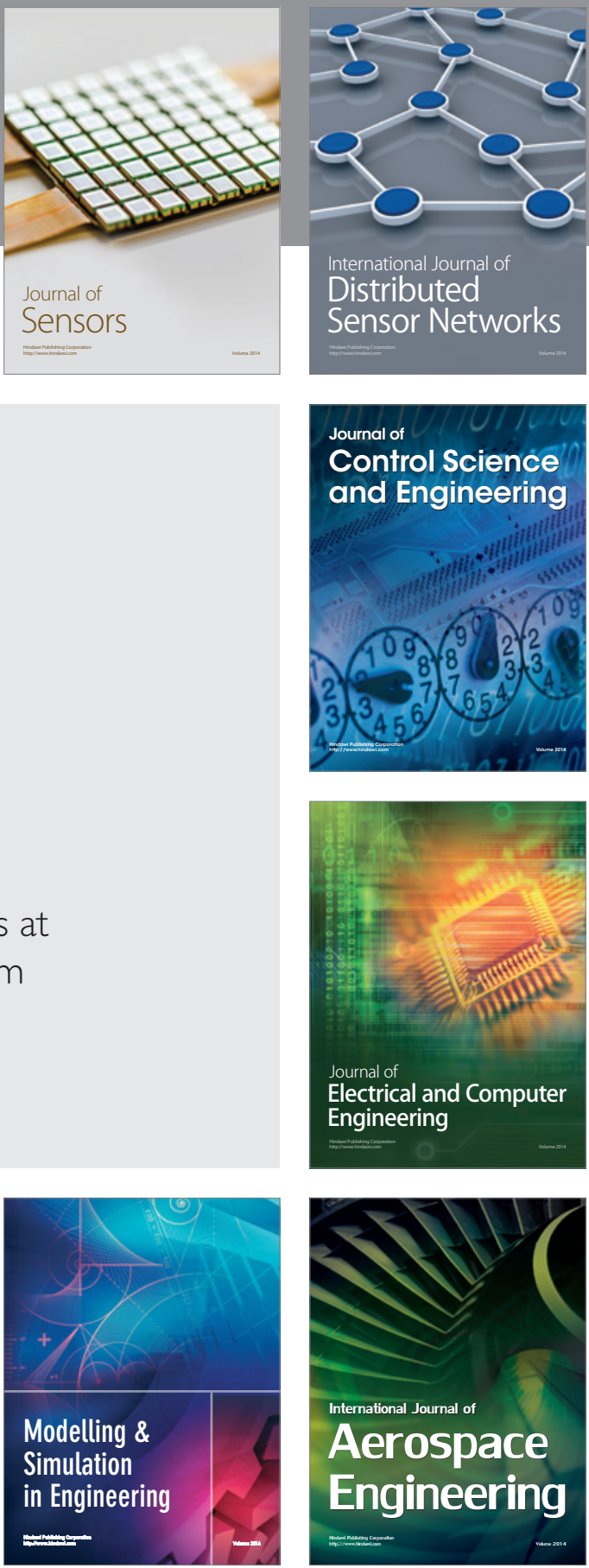

Journal of

Control Science

and Engineering
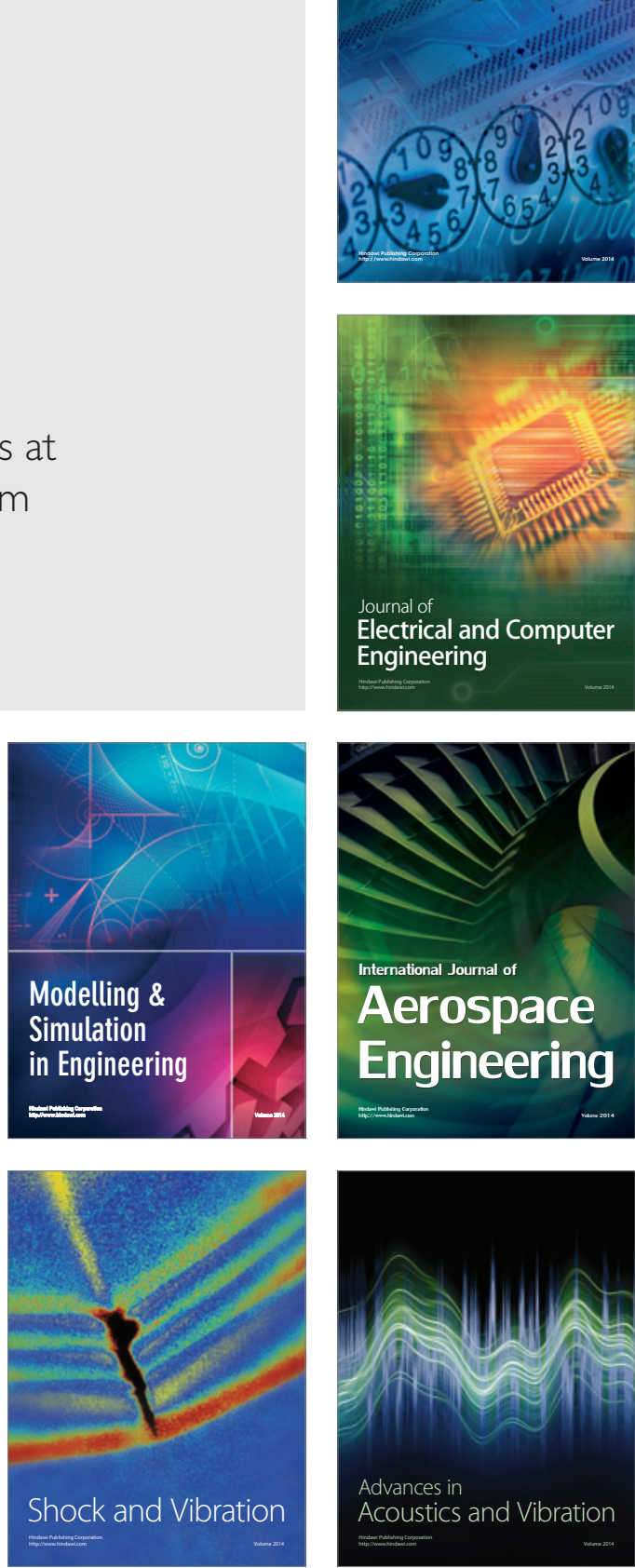